\title{
CONSIDERATIONS ON THE NECESSITY OF USING THE CONCEPT OF PUBLIC ADMINISTRATION IN THE CONSTITUTIONAL FOUNDATION OF PUBLIC ADMINISTRATION IN THE FUTURE CONSTITUTION
}

\author{
A. L. Nicu
}

\author{
Alina-Livia Nicu \\ Faculty of Law and Administrative Science \\ Craiova University, Craiova, Romania \\ *Correspondence: Alina Livia Nicu, Craiova University, 107D Calea Bucuresti, Craiova, \\ Romania \\ E-mail: nicu1940ion@gmail.com
}

\begin{abstract}
Beginning with the current social reality which described political actors preoccupied with the review of the Romanian Constitution, the present paper outlines the idea that the new Romanian Constitution has to offer, more than ever, the foundation for a clear, precise, coherent and concise legislation. This necessity is felt in all the areas related to the social life, but especially in public administration. Given that it is the moment for debates at the level of the society regarding how the future Constitution must look like, it has been asserted as appropriate to recall into discussion an idea stated since 2003 at monograph level. According to this idea, in the activity of molding the system of structures exerting public power prerogatives in general and molding the Romanian administrative system in particular, it is necessary and useful to use the concept of public institution as construction element used to craft the architecture the legislator desires. The proposal is argued as a critical analysis of reference regulations in this area. Proposals for lege ferenda are also made.
\end{abstract}

Keywords: public institution, public authority, public administration, Constitution, legislative clarity and coherence.

\section{Introduction}

In the past few years and in many cases, the Romanian legislation cannot be characterized as being stable and coherent. If regarding the excessively dynamic character of some judicial norms it is possible to justify that the dynamic of social relations in that area itself determine the frequent modification of the content of those norms, regarding the coherence and correlation there can be no justification.

As close observant of the social relations created between the personnel in the public administration and citizens and the social relations inside the structure namely public administration, since 1999, I felt that the tendency of the social actors exerting prerogatives of public power at the highest level to always start from the beginning and permanently redefine the social relations has affected the quality of the activity of regulation.

My preoccupation is centered on the pattern of the Romanian administrative system and the clarification of the content of the concept of public institution and public authority, the public institution being the basic structural element of the edifice that is the Romanian public administration system.

Beginning with the current social reality which described political actors preoccupied with the review of the Romanian Constitution, the present paper outlines the idea that the new 
Romanian Constitution has to offer, more than ever, the foundation for a clear, precise, coherent and concise legislation. This necessity is felt in all the areas related to the social life, but especially in public administration. Given that it is the moment for debates at the level of the society regarding how the future Constitution must look like, it has been asserted as appropriate to recall into discussion an idea stated since 2003 at monograph level ${ }^{1}$. According to this idea, in the activity of molding the system of structures exerting public power prerogatives in general and molding the Romanian administrative system in particular, it is necessary and useful to use the concept of public institution as construction element used to craft the architecture the legislator desires.

\section{Legal and doctrine determinations related to the usefulness of the subject}

By analyzing the regulations in the Romanian Constitution reviewed in 2003, we observed that the following collocations are used: public authority (article 25, paragraph (1)), public authority (article 44, paragraph (5)), public authorities (article 26, paragraph (1); article 31, paragraph (2); article 49, paragraph (5); article 51, paragraph (4); article 59, paragraph (2); article 146, lit. e; name of the Title III), public auhtorities (article 16, paragraph (1); article 51, paragraph (1); article 80, paragraph (2); article 126, paragraph (6)), authorities of the public administration (article 121, paragraph (1)), Public administration authority (article 122, paragraph (1)), local public administration authorities (article. 16, paragraph (4)), autonomous administration authorities (article 116, paragraph (2); article 117, paragraph (3) and article 121, paragraph (2)), legislative authority (article 61, paragraph (1)), public services (article 120; article 123, paragraph (2)), judicial authority (article 148, paragraph (4)).

The concept public institutions was used in the first Fundamental law after the restoration of the state of law in Romania in a single article (article 136) and only related to the formation, administration, use and control of the financial resources, specifically with the state "financial system". In the current form of the Constitution, the concept of public institutions is presented in articles 136 and 137, related to rendering for administration of goods from public domain and the formation, administration, use and control of the financial resources of the state.

The Romanian legislation defines the public institution as a multitude of social structures $^{3}$ including what the Constitution defines as being public authorities. A series of questions are therefore shaped: the public authorities and public institutions have to be understood as being distinct types of entities? They complete each other or have areas of interference? Isn't authority found in institution? Isn't the phrasing "authority and public institution" redundant in judicial language?

Due to the ways of regulation found in the Romanian legislation at different moments in time, the literature has offered many perspectives regarding the concept of public institution. Therefore, regarding the public institutions as social constructions established for the satisfaction of general interests of the members of a community, several opinions have been stated. In a first opinion ${ }^{4}$, regarding the subjects that can administer, rent and concession

\footnotetext{
${ }^{1}$ Alina Livia Nicu, Instituția publică in dreptul administrativ, "Universitaria” Publishing House, Craiova, 2003.

2 Article 136: "(1) The formation, administration, use and control of the financial resources of the state, the administrative-territorial units and public institutions are regulated by law".

${ }^{3}$ For example, in article 2 - Definitions- Paragraph 30 in Law 500/2002 on the public finances the following definition is formulated "Public institutions- generic denomination that includes the Parliament, Presidential Administration, ministries, the other special organs of public administration, other public authorities, autonomous public institutions as well as the institutions subordinated to them, irrespective of their way of financing". Also, in article 1 of Law 273/2006 on the local public finances it is stated: "(1) The present law establishes the principles, general framework and procedures on the formation, administration, engagement and use of local public funds, as well as the responsibilities of the local administration authorities and public institutions involved in the sector of local public finances".

${ }^{4}$ A. Iorgovan, Tratat de drept administrativ, $2^{\text {nd }}$ volume, "Nemira" Publishing House, Bucharest, 1996, page 106.
} 
goods or public services in Romania, discussing the "public institution as authority that administrated the public domain" it has been appraised that "The notion of public institution, by elimination, evokes, in broad sense, any organ of the state or autonomous local administration that is neither overhead nor company". An observation is made that the text of the Constitution considers a narrower meaning and proposes as constitutional collocation to be "interpreted in a restrictive meaning evoking the idea of a structure exclusively budgetary of the public administration, more specifically: 1) ministries and organs subordinated to the Government; 2) authorities of the central special administration; 3) authorities subordinated to the ministries or central autonomous authorities and 4) institutions subordinated to the county councils or local councils". 5

In another opinion ${ }^{6}$ indicating that the state of law accomplishes its tasks and attributions through public services, a classification of the public services is proposed as follows: "a) administrative public services organized as organs of public administration; (...) b) public services organized as public institutions, which can be education (...), culture (...), health (...), scientific research, radio and television, information, legal medicine (...)". The opinion $^{7}$ that the notion of public institution is correspondent, to a certain extent, to the one of "organ of public administration" has also been forwarded.

In the French literature the collocation "institutions administrative" 8 is used. For example, Henry Puget wrote?: "Au-dessous des institutions politiques existent des institutions administratives; elles permettent à l'État de vivre et de satisfaire aux besoins communs du groupe, conformément aux décisions qui dégagent du jeu des institutions politiques (...)”. Charles Debbasch states that the administrative insitutions and the political institutions are equally public insitutions. He asserts: "Les problèmes d'administration ne sont pas en eux mêmes spécifiques. Le terme administration, à lui seul, est synonyme de gestion (...). Il est applicable aussi bien aux institutions publiques qu'aux institutions privées". "Commes les institutions administratives, les institutions politiques sont des institutions publiques". ${ }^{10}$

A question arises then: are the public authorities and public institutions distinct entities?

\section{Interpretation of the concept of public institution}

In our opinion, the public institution is a human collectivity constituted based on, and for the enforcement of law, equipped with material and financial means according to the law, legal entity and necessary competence to act in order to define those social values that are considered to be fundamental for a micro or macro collectivity and their consecration in judicial norms, to act for the organization of execution, effective execution and assurance of execution of the law, that collectivity being integrated in one of the systems of structures through which the legislative public service, the judicial public service or administrative public services are accomplished, with the purpose that, through the application of law, will obtain the satisfaction of the social requests of public interest.

In what concerns the answer to the question: "Which is the relation between the concept of public authority and public institution?" we assert that the relation between the

\footnotetext{
${ }^{5}$ Idem.

${ }^{6}$ V. I. Prisăcaru, Actele şi faptele de drept administrativ, "Lumina Lex” Publishing House, Bucharest, 2001, page 49.

7 A. Negoi $\square$ ă, Drept administrativ,” Sylvi” Publishing House, Bucharest, 1996, page. 65.

${ }^{8}$ For example, the papers: Jean-Marie Auby et Robert Ducos-Adèr, Institutions administratives, Dalloz, Paris, 1966; Charles Debbasch, Institutions administratives, $3^{\mathrm{e}}$ édition, Librairie générale de droit et de jurisprudence, Paris, 1975; Henry Puget, Les institutions administratives étrangères, Dalloz, Paris, 1969.

${ }^{9}$ H. Puget, op. cit., page 7: "The ins and outs of the political institutions are the administrative institutions; they allow the state to exist and satisfy the common needs of the group, according to the decisions resulting from the game of the political institutions".

${ }^{10}$ C. Debbasch, op. cit., page 9: "The issues of the administration are not themselves specific. The term administration, alone, is synonym to inventory. It is applicable as well to public institutions as to private institutions" and page 10 "As well as the administrative institutions, the political institutions are public institutions".
} 
concept of public authority and the concept of public institution is established using the concept of competence of public institution. "The authority is the right, empowerment to command, to instruct or impose obedience to someone. ${ }^{11}$ In consequence, authority results from the competence of the public institution. It is a characteristic of the latter due to which it can accomplish its mission and is found in the attributions of each dignitary or public servant and in the legal investment of these categories of personnel. This is of course the functional significance of the term authority. Regarding the organizational meaning, authority can be perceived as that structural element - unipersonal or collegial- from the public institution with decisional attributions and with right of command and control related to the respect and execution of decisions. Irrespective the meaning that is taken into consideration, functional or organizational, the term authority is in a relation of inclusion with the term public institution, the latter enclosing the first. ${ }^{12}$

\section{Application of the concept of public institution on the text of the Romanian Constitution in reviewed form}

Given the space limitations of such a study, we will limit ourselves to the application of our interpretation regarding the concept of public instruction on the current version of the Fundamental law, in order to demonstrate that the theory is applicable, without complications in practice, but eliminating certain undesired situations in the judicial practice consisting in discussions regarding especially the passive procedural quality or the active one of the public institutions. ${ }^{13}$ Thus, following the current text of the Constitution we asses that the following formulations are necessary and useful:

- Article 16, paragraph (1): "The citizens are equal in front of the law and the public institutions, without privileges and discrimination. The public institution represents a human coactivity constituted based on and for the exertion of the law, equipped with material and financial means in virtue of the law, with legal entity and necessary competence to act for the definition of those social values considered fundamental for a micro or macro community and their consecration in judicial norms, to act for the organization of execution, effective execution and assurance of the execution of law, that collectivity being integrated in one of the systems of structures through which the public legislative service, public judicial service or administrative public services are accomplished, with the purpose that, through the application of the law, the satisfaction of all the demands of public interest is accomplished."

- Article 26, paragraph (1): "The public institutions respect and protect the intimate, family and private life".

- Article 31, paragraph (2): "The public institutions, according to their competencies are obliged to ensure the correct information of the citizens on the public tasks and on the issues of personal interest".

Article 44, paragraph (5): "For works of general interest, the public institutions with legal competence in matter can use the basement of any estate property, with the obligation to compensate the owner for the damages caused to the soil, plantations or constructions, as well as for other damages imputable to the public institution".

\footnotetext{
${ }^{11}$ DEX, quoted, page 75.

${ }_{12}$ Alina Livia Nicu, op. cit., page 158.

${ }^{13}$ The most eloquent example is the one of the "city hall" that, until the clarification in article 21 in Law on the local public administration no.215/2001 that "(1) The administrative- territorial units are legal persons of public law, with full judicial capacity and own patrimony. They are judicial subjects of fiscal law, holders of sole registration code and accounts opened at the territorial treasury units as well as banking units. The administrative- territorial units are holders of rights and obligations deriving from the contracts for administration of goods belonging to the public and private domain to which they are part as well as from the relations with other private or judicial entities, under the conditions of law. (2) In justice, the administrativeterritorial units are represented, depending on the case, by the mayor or by the president of the county council" was always called in justice especially in the cases involving the right to property or in cases in which rulings with the effect of authentic acts were requested.
} 
- Article 49, paragraph (5): "The public institutions have the obligation to contribute to the assurance of the conditions for the free participation of the youth to the political, social, economic, cultural and sportive life of the country".

- Article 51, paragraph (1): "The citizens have the right to address to the public institutions through petitions formulated in the name of the signatories".

- Paragraph (4): "The public institutions have the obligation to answer the petitions in the terms and conditions established by law".

- Article 52, paragraph (1): “The one whose legitimate rights or interests have been damaged by a public institution, by an illegal administrative act or by lack of solution in the legal term of a request related to a legitimate right or interest, is entitled to obtain recognition of the claimed right or interest, annulment of the act and repair of the damage".

- Article 59, paragraph (2): "The public institutions are obliged to ensure the Ombudsman the necessary support in exerting his attributions".

- Title III will be named: "Public institutions through which the public legislative service, public judicial service and public administration are accomplished".

- Article 61, paragraph (1): "The Parliament is the sole public institution through which the legislative public service is accomplished".

- Paragraph (2): "The public authority within this institution has two components: Chamber of Deputies and Senate".

- Article 80, paragraph (2): "The President of Romania watches over the respect of the Constitution and the good functioning of the public institutions. To this end, the President exerts the role of mediator between the state and society, as well as between the public institutions accomplishing the tasks of the state".

- Article 116, paragraph (2): "Other special public institutions can be organized under the authority of the Government or the ministries or as autonomous administrative public institutions".

- Article 117, paragraph (2): "The Government and ministries, with the approval of the Court of Accounts, can establish special public institutions in their subordination, only if the law recognizes this competence".

- Paragraph (3): "Autonomous public institutions can be established in virtue of an organic law".

- Article 121, paragraph (1): "In communes, cities, municipalities, local councils are established through which the local autonomy is accomplished. The public institution named local council comprises the deliberative authority local council, which comprises local counselors, mayor as executive authority, deputy mayors, secretaries of the administrativeterritorial unit and the special technical system under the subordination of the mayor. The local counselor and mayors are elected by the residents of that city, by universal, equal, direct, secret and free vote".

- Paragraph (2): "The public institution named local council acts in virtue of the law, and autonomous administrative public institution and solves the public issues in the communes, cities and municipalities".

- Paragraph (3): "And in the administrative- territorial subdivisions of the municipalities the public institution named local council can be established".

- Article 122, paragraph (1): "County councils are established in counties as autonomous administrative public institutions for the coordination of the activity of local councils, in order to accomplish the public services of county interest. The public institution named county council comprises the deliberative authority county council, which comprises county councils, president of the county council as executive authority, vice-presidents, technical apparatus subordinated to the president of the county council. The county counselors and president of the county council are elected by the residents of the county, by universal, equal, direct, secret and free vote".

- Article 123, Institution of the prefect 
- In each county and in Bucharest the institution of the prefect is established as a public institution. The institution comprises the prefect, as public authority, deputy prefect and the special technical apparatus subordinated to the prefect. The prefect is invested by the Government, based on competition.

- The prefect is the representative of the Government at local level and conducts the deconcentrated public services of the ministries and the other entities in the central public administration in the administrative-territorial units.

- The attributions of the prefect are established by organic law.

- Between the institution of the prefect on one side and the institution of the local council and the institution of the county council on the other side, there are no relations of subordination".

- Title of Chapter VI: "Public institutions through which the judicial public service is accomplished"

- Article 125, paragraph (1): "Public institutions through which justice is performed are the High Court of Cassation and Justice and the other judicial instances established by law".

- Article 136, paragraph (4): "The goods belonging to the public property are inalienable. Under the conditions of the law, they can be given for administration to the public institutions or can be chartered or rented. Also, they can be given for free use to institutions of public utility".

In case the establishment of regions will be completed, the theory remains applicable at regional level, with the establishment of a regional public institution that will comprise a deliberative authority (collegial or unipersonal), an executive authority and a special technical apparatus subordinated to the deliberative or executive authority, depending on the case and according to the social, political and judicial role created by the legislator for the region and the regional public institution.

\section{Conclusions}

As can be observed from the brief exemplification with proposals of lege ferenda in chapter 4, if the Romanian legislation would use the concept of public institution with the interpretation proposed hereby, everything would be simpler. Any citizen would clearly know that everything that serves, through decision or performance, the interest of the citizens is a public institution. Any citizen would also know that in any public institution there is a deliberative and executive authority and their actions are operatively sustained by a special technical apparatus. The members of the parliament themselves, in elaborating the judicial norms, would have, as starting point, a simple and clear concept about the system of structures exerting the prerogatives of public power. Practically, we would work only with the concept of public institution and, if in the law of organization or functioning of such a structure it is desired that the weight is held by the activities of disposition and control, this will be observed in the regulation or denomination. For example, a structure is to be named "authority". The title of the normative act would be: "Law on the functioning and organization of the Authority..." following that the subsequent article would state that "The present law establishes the Authority...as public institution", in the text and probably in an annex representing a generic organizational chart, the structure with deliberative and executive role would be presented, followed by the personnel categories etc. 


\section{Bibliography}

Alina Livia Nicu, Instituția publică în dreptul administrativ, "Universitaria" Publishing House, Craiova, 2003.

V. I. Prisacaru, Actele şi faptele de drept administrativ, "Lumina Lex" Publishing House, Bucharest, 2001;

A. Iorgovan, Tratat de drept administrativ, $2^{\text {nd }}$ volume, "Nemira" Publishing House, Bucharest, 1996;

A. Negoita, Drept administrativ, Sylvi Publishing House, Bucharest, 1996;

C. Debbasch, Institutions administratives, $3^{\mathrm{e}}$ édition, Librairie générale de droit et de jurisprudence, Paris, 1975;

H. Puget, Les institutions administratives étrangères, Dalloz, Paris, 1969;

Jean-Marie Auby, R. Ducos-Adèr, Institutions administratives, Dalloz, Paris, 1966; DEX, "Universul Enciclopedic" Publishing House, Bucharest. 